\title{
COVID-19 in a Child with Primary Antibody Deficiency
}

Hamid Ahanchian ${ }^{1}$, nasrin moazzen ${ }^{1}$, Mohammad Hasan Aelami ${ }^{1}$, Majid Sezavar Dokht Faroughi $^{1}$, nasrin sadat Motevalli Haghi ${ }^{1}$, negar khalighi ${ }^{1}$, maryam Khoshkhui ${ }^{1}$, and nima rezaei $^{2}$

${ }^{1}$ Mashhad University of Medical Sciences

${ }^{2}$ Tehran University of Medical Sciences Childrens Hospital

September 11, 2020

\begin{abstract}
Although children are less affected by Novel coronavirus disease 2019 than adults, it should not be missed, especially in those with underlying diseases. Herein, we report a patient with primary antibody deficiency, who was affected with COVID-19. This infection could be presented mildly in patients with immunodeficiency.
\end{abstract}

\section{Hosted file}

case presentation PAD.docx available at https://authorea.com/users/358356/articles/480605covid-19-in-a-child-with-primary-antibody-deficiency

\section{Hosted file}

PAD NEW.docx available at https://authorea.com/users/358356/articles/480605-covid-19-in-achild-with-primary-antibody-deficiency

\section{Hosted file}

Figure 1.docx available at https://authorea.com/users/358356/articles/480605-covid-19-in-achild-with-primary-antibody-deficiency 